\title{
The histone acetylase PCAF is a nuclear receptor coactivator
}

\author{
Jorge C.G. Blanco, ${ }^{1,4}$ Saverio Minucci, ${ }^{1}$ Jianming Lu, ${ }^{1}$ Xiang Jiao Yang ${ }^{1}$ Kristen K. Walker, ${ }^{3}$ \\ Hongwu Chen, ${ }^{3}$ Ronald M. Evans, ${ }^{2,3}$ Yoshihiro Nakatani, ${ }^{1}$ and Keiko Ozato ${ }^{1,5}$ \\ ${ }^{1}$ Laboratory of Molecular Growth Regulation, $\mathrm{N}$ ational Institute of Child Health and Human Development, $\mathrm{N}$ ational \\ Institutes of Health (NIH), Bethesda, Maryland 20892-2753 USA; ${ }^{2}$ Howard Hughes M edical Institute; ${ }^{3}$ The Salk Institute \\ for Biological Studies, La Jolla, California 92037 USA
}

\begin{abstract}
Whereas the histone acetylase PCAF has been suggested to be part of a coactivator complex mediating transcriptional activation by the nuclear hormone receptors, the physical and functional interactions between nuclear receptors and PCAF have remained unclear. Our efforts to clarify these relationships have revealed two novel properties of nuclear receptors. First, we demonstrate that the RXR/RAR heterodimer directly recruits PCAF from mammalian cell extracts in a ligand-dependent manner and that increased expression of PCAF leads to enhanced retinoid-responsive transcription. Second, we demonstrate that, in vitro, PCAF di rectly associates with the DNA-binding domain of nuclear receptors, independently of p300/CBP binding therefore defining a novel cofactor interaction surface. Furthermore, our results show that dissociation of corepressors enables ligand-dependent PCAF binding to the receptors. This observation illuminates how a ligand-dependent receptor function can be propagated to regions outside the ligand-binding domain itself. On the basis of these observations, we suggest that PCAF may play a more central role in nuclear receptor function than previously anticipated.
\end{abstract}

[Key Words: Histone acetylation; PCAF; RXR; RAR; steroid receptors; retinoids]

Received N ovember 3, 1997; revised version accepted A pril 14, 1998.

Ligand-dependent gene expression is regulated by transcription factors belonging to the nuclear hormone receptor superfamily (Beato 1989; Tsai and O'Malley 1994). Receptors of the class II subfamily, such as retinoic acid receptor (RAR), thyroid hormone receptor (TR), and other receptors bind to specific DN A elements as a heterodimer with a retinoid $X$ receptor ( $R X R$; Mangel sdorf and Evans 1995; Chambon 1996). Receptors heterodimerized with RXR are generally more stable than homodimers, and thus are thought to be a functional unit for transcriptional activation at many promoters (Forman et al. 1995; Chambon 1996; M inucci and Ozato 1996).

These heterodimers interact with various other transcription factors to elicit their activities (Horwitz et al. 1996). They also associate with basal transcription factors, such as TFIIA, TFIIB (Blanco et al. 1995; Fondell et al. 1996; Lemon et al. 1997), TBP (Sadovsky et al. 1995; Schulman et al. 1995), and $T_{A F} F_{11}$ (Jacq et al. 1994; Schwerk et al. 1995), which may help stabilize the preinitiation complex formed at the basal promoter. We and others have demonstrated that receptors may utilize a variety of other proteins that function as hormone-de-

\footnotetext{
${ }^{4}$ Department of Microbiology, Uniformed Senvice University Health Science, Bethesda, Maryland 20814 USA.

${ }^{5}$ Corresponding author.

E-MAIL ozatok@dir6.nichd.nih.gov; FAX (301) 480-9354.
}

pendent cofactors. This group includes SRC-1 (Oñate et al. 1995) and SRC family members p160 (Kamei et al. 1996), p/CIP (Torchia et al. 1997), and ACTR (Chen et al. 1997). These coactivators have been shown to bind to multiple nucl ear receptors to enhance ligand-dependent transcription. Another set of cofactors in this group includes the CREB-binding protein (CBP) and the related p300 (Janknecht and Hunter 1996). They bind to RAR, TR, and RXR (Chakravarti et al. 1996; Kamei et al. 1996) through the carboxy-terminal AF-2 domain (Danielian 1992; Leng et al. 1995) and affect ligand-dependent transcription. CBP and p300 also interact with AP-1, which may account for inhibition of ligand-dependent transcription by AP-1 and vice versa (Lucibello et al. 1990; Yang et al. 1990; Sal bert et al. 1993). CBP and p300 are shown to interact with the former set of cofactors, suggesting that they form a large coactivator complex (Chakravarti et al. 1996; Kamei et al. 1996; Yao et al. 1996; T orchia et al. 1997). The recent findings that some of these cofactors have histone acetylase activity (Bannister and Kouzarides 1996; Ogryzko et al. 1996; Chen et al. 1997; Mizzen et al. 1997) suggest that they influence transcription by regulating acetylation of nearby histones.

Several independent lines of evidence indicate that transcriptionally active chromatin is composed of nucleosomes of acetylated histones (T urner and O'N eil 1995; Brownell and Allis 1996; Wolffe and Pruss 1996). 
Cloning of a histone acetylase from Tetrahymena, and the mammalian PCAF, both homologous to the yeast transcription adaptor GCN5, strengthened the role of histone acetylation in enhanced gene transcription, as yeast GCN 5 was later shown to be a histone acetylase (Brownell et al. 1996; Yang et al. 1996).

The second group of cofactors consists of so called corepressors, such as SMRT (Chen and Evans 1995) and N-CoR (Rip 13) (Horlein et al. 1995; Seol et al. 1996), which interact with the receptors in the absence of $\mathrm{Ii}$ gand to repress transcription. They bind to the hinge region of RAR, TR, and $R X R$ and are released from the receptor upon ligand addition. Interestingly, recent reports show that the corepressors are part of the histone deacetylase-sin 3 complex (Alland et al. 1997; Heinzel et al. 1997; N agy et al. 1997), suggesting that their repressive activity may be associated with deacetylation of Iocal histones (Wolffe and Pruss 1996). Although the mechanism by which these cofactors affect transcription has not been fully elucidated, one can envisage that the coactivators and corepressors act by modulating acetylation of local histones in an opposing fashion.

The work described here began with an analysis of factors expressed in mammalian cells that associate with a recombinant RXR-RAR heterodimer bound to the retinoic acid-responsi ve element (RARE). We show that the RARE-bound heterodimer recruits endogenous PCAF upon retinoid addition, which results in the accumulation of histone acetylase activity on the heterodimerDN A complex. In vitro studies indicate that the recruitment does not require p300, which is known to interact with the receptors. The PCAF-heterodimer interaction required the DNA-binding domain of either receptor. Moreover, interaction with PCAF was demonstrated with several steroid receptors including estrogen (ER), glucocorticoid (GR), and androgen (AR) receptors. Binding assays carried out with corepressors SMRT and $\mathrm{N}$-CoR (RIP13) led us to suggest a model in which the heterodimer interacts with PCAF in coordination with ligand-induced rel ease of a histone deacetylase-corepressor complex from the receptors. Finally, in support of the functional importance of histone acetylase recruitment by the heterodimer, transfection of PCAF into N IH-3T 3 cells potentiated ligand-dependent transcription from a retinoic acid-responsive reporter.

\section{Results}

The RXR-RAR heterodimer recruits cellular PCAF in a ligand-dependent manner

To study nuclear factors that interact with the RXRRAR heterodimer, we employed a beads binding assay using recombinant $R X R \beta$ ( $r R X R \beta)$ and $R A R \beta$ (rRAR $\beta$ ) that had been bound to the RARE (DR-5) conjugated to agarose beads (see diagram in Fig. $1 A$ ). rRXR and rRAR are known to bind to the RARE as a heterodimer with a defined polarity in a ligand-independent manner in vitro (Kurokawa et al. 1993; Perlmann et al. 1993). A total of 10-30 pmoles of heterodimer was reacted with 30 pmole of the RARE fragment. Data in Figure 1B show that equival ent amounts of $r R X R \beta$ and $r R A R \beta$ bound to the RARE beads in a dose-dependent manner, and independently of ligand, 9-cis RA (Heyman et al. 1992; Levin et al. 1992). The heterodimer-RARE complexes were then incubated with nuclear extracts from human $B$ cells in the presence or absence of 9-cis RA, and bound materials were eluted and analyzed by immunobl ot assay. M aterials precipitated with the heterodimer-RARE beads contained PCAF, which was detected in a receptor-dose-dependent fashion and only when 9-cis RA was added to the reaction (Fig. 1B; lanes 3,5,7). A human homolog of the yeast adaptor ADA2, known to associate with yeast GCN 5 (Berger et al. 1992; Horiuchi et al. 1995; Candau et al . 1996), was also found with the heterodimer-RARE complex, again only in the presence of 9-cis RA (Fig. 1B; hADA2). This is likely to be attributable to the interaction of ADA2 with PCAF, as a recombinant hADA 2 was found to bind to PCAF in vitro (X-J. Yang and Y. Nakatani, unpubl.). Although human GCN5 appeared to be present in the nuclear extracts at some level, it was not detected with the heterodimer-RARE complex, perhaps because of low sensitivity (not shown). p300, a coactivator shown to interact with the ligand-bound heterodimer (Chakravarti et al. 1996; Janknecht and Hunter 1996; Kamei et al. 1996), also bound to the heterodimer-RARE complex in a 9-cis RA-dependent manner. Comparing the rel ative amounts of PCAF found in the free and ound fractions with those of p300 (Fig. 1B; lane 7 vs. Iane 8), it was evident that a relatively large fraction of PCAF in the extract was recruited to the heterodimer, while only a small fraction of the total p300 present in the extracts bound to the heterodimer complex. In support of the view that recruitment of PCAF by the heterodimer is more efficient than that of p300, quantitative immunoblot assays with recombinant factors showed that the anti-PCAF antibody used here was twofold less sensitive than anti-p300 antibody (not shown). Similar to p300, the homologous cofactor, CBP was also found with the heterodimer-RARE complex at a low level (data not shown). Binding of these proteins to the heterodimerRARE complex was specific, since other abundant nuclear proteins such as YY1 (Shi et al. 1991) (Fig. 1B) or HMG14 (Bustin et al. 1990) (data not shown) were not found in the bound fractions.

$M$ aterials bound to the heterodimer-RARE complexes were then assayed for histone acetylase activity. As shown in Figure 1C, significant levels of histone acetylase activity were recovered only from samples in which binding was performed in the presence of 9-cis RA. The levels of histone acetylase activity correlated with the amounts of heterodimer bound to the RARE-conjugated beads. With the highest amount of heterodimer $(3 \mu \mathrm{g})$, histone acetylase activity recovered from the RARE-conjugated beads was 12-fol d higher than that from the control beads without receptor, which accounted for $~ 1.5 \%$ $4 \%$ of the total histone acetylase activity in the nuclear extracts. These results indicate that histone acetylase activity accumulates on the ligand-bound heterodimerRARE complex. 
Figure 1. Ligand-dependent recruitment of PCAF by the RXR-RAR heterodimerDNA complex. (A) Binding assay. Recombinant $R X R \beta$ and $R A R \beta$ were bound to a DNA fragment containing the RARE (DR5) fixed to agarose beads, and incubated with nuclear extracts. Bound materials were tested in B-E. (B) Immunoblot analysis. Nuclear extracts (3 mg) were incubated with the indicated amounts ( $\mu \mathrm{g}$ of protein) of RXR-RAR heterodimer bound to the RARE-conjugated beads in the presence $(+)$ or absence $(-)$ of $1 \mu \mathrm{m}$ 9-cis RA, and bound materials were detected by immunobl ot assay with the appropriate antibodies. (Lane 1) Extracts added to RARE-conjugated beads without receptors. (Input) 40 $\mu \mathrm{g}$ of nuclear extracts. Numbers at the right indicate molecular masses of the immunoreactive proteins. (Bottom) Binding of $r R X R \beta$ and rRAR $\beta$ to the RARE-conjugated beads as detected by immunobl ot assay. (C) Histone acetylase activity recovered from the heterodimer-RARE complex. Extract proteins bound to the indicated amounts of heterodimer-RARE complexes in the presence of $1 \mu \mathrm{M}$ 9-cis RA $(\diamond)$ or absence $(\square)$ were tested for histone acetylase activity. Values represent the average of four independent assays \pm .D. (D) Histone specificity of acetylase activity tested with free core histones. Approximately $3 \mu \mathrm{g}$ of bound protein obtained from heterodimer-RARE complexes ( $3 \mu \mathrm{g}$ of heterodimer) was tested for acetylation activity with free histones. (Lane 1) Acetylation pattern by rPCAF (50 ng). (Lane 2) Acetylation pattern by eluates from control beads. (E) Histone specificity of acetylase activity tested with nucleosomal histones. Bound materials obtained from $1 \mu \mathrm{g}(+$, lanes 4,5$)$ or $2 \mu \mathrm{g}(++$, lanes 6,7$)$ of heterodimers were tested for acetylase activity with nucleosomal histones. (Lane 2) Background control without rPCAF or bound materials.

\section{Specificity of histone acetylase activity}

Histone acetylase activity recovered from the heterodimer-RARE complex may represent not only PCAF but other acetylases, including p300 and CBP (Bannister and Kouzarides 1996; Ogryzko et al. 1996), as well as coactivators of the SRC family (Oñate et al. 1995; Chen et al. 1997). Previous work showed that PCAF targets predominantly histones $\mathrm{H} 3$ and $\mathrm{H} 4$ both in the core histones and nucleosomal histones, but has little activity for histone $\mathrm{H} 2 \mathrm{~A}$ and $\mathrm{H} 2 \mathrm{~B}$. In contrast, p300 and CBP are shown to acetylate all four core histones (Bannister and Kouzarides 1996; Ogryzko et al. 1996). Histone specificity of the acetylase activity recovered from the heterodimer-RARE complex above was tested in experiments shown in Figure 1D and E. For both free and nucleosomal histones, acetylation was found predominantly for histone $\mathrm{H} 3$ and, to a lesser degree, for histone $\mathrm{H} 4$, but little for histones $\mathrm{H} 2 \mathrm{~A}$ and $\mathrm{H} 2 \mathrm{~B}$. This specificity pattern is similar to that of PCAF (see Fig. 1D,E, lane 1). These results suggest that PCAF, rather than p300/CBP, accounts for much of histone acetylase activity recovered from the heterodimer, consistent with data in Figure 1B showing that PCAF was recruited more efficiently than p300 and CBP by the heterodimer.

\section{9-cis RA dose response and ligand selectivity}

The effects of 9-cis RA concentrations on the recruitment of PCAF and p300 were investigated in Figure 2A. $A$ low level of PCAF was seen in the heterodimer at $10^{-8}$ $M$ of 9-cis RA (Fig. 2A, lane 4), but PCAF levels were significantly increased at higher concentrations of 9-cis $\mathrm{RA}$, reaching the maximum at $10^{-6} \mathrm{M}$. On the other hand, p300 recruitment was detected at lower concentrations of 9-cis RA $\left(10^{-9} \mathrm{M}\right)$, at which PCAF recruitment was undetectable, and which increased only slightly with increased concentrations of 9-cis RA.

While only a low level of histone acetylase activity was detected with lower concentrations of 9-cis RA (10 $10^{-9}$ and $\left.10^{-8} \mathrm{M}\right)$, much greater activity was recovered at higher concentrations $\left(10^{-7}\right.$ and $\left.10^{-6} \mathrm{M}\right)$, which roughly corresponded to the pattern of PCAF recruitment. Previously, we found that 9-cis RA stimulates transcription at $10^{-7}$ to $10^{-6} \mathrm{M}$ (Minucci et al. 1997), suggesting that re 
A

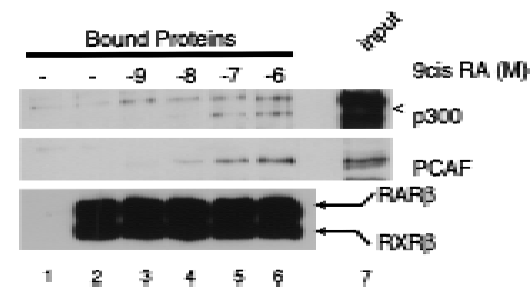

C

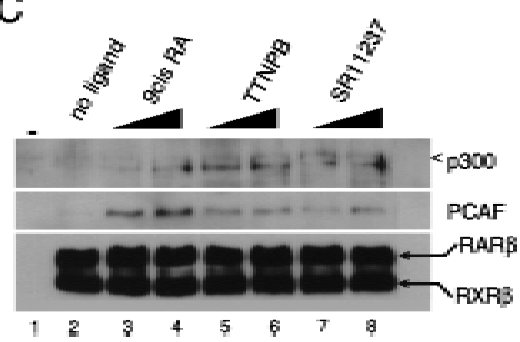

B

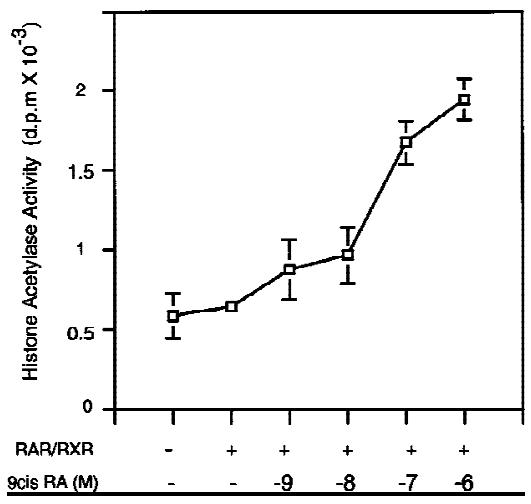

D

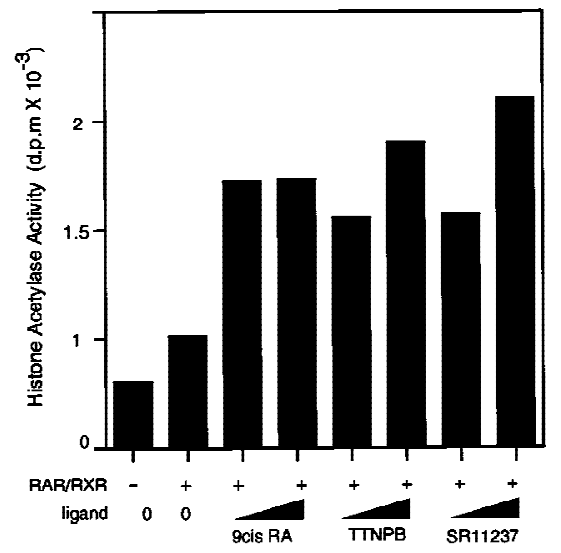

Figure 2. The role of ligand in PCAF recruitment: Dose response and receptor selectivity. (A,B) 9-cis RA concentration dependence. One microgram of heterodimer bound to RARE-conjugated beads was incubated with indicated concentrations of 9-cis RA and tested for recruitment of PCAF and p300 (A) from nuclear extracts as in Fig. 1B or for accumulation of histone acetylase activity (B). (Bottom) RXR-RAR bound to RARE-conjugated beads. (C,D) Receptor selectivity. One microgram of heterodimers bound to RARE-conjugated beads was incubated with 9-cis RA $\left(10^{-7}\right.$ and $\left.10^{-6} \mathrm{M}\right)$, TTN PB $\left(10^{-9}\right.$ and $\left.10^{-8} \mathrm{M}\right)$, OR SR $11237\left(10^{-6}\right.$ AND $10^{-5} 5 \mathrm{M}$ ) and tested for binding of PCAF and p300 (C) or for accumulation of histone acetylase activity (D). cruitment of PCAF occurs at physiologically active concentrations of the ligand.

Because 9-cis RA binds to both RXR and RAR (Heyman et al. 1992; Levine et al. 1992), it was not possi bleto determine whether PCAF recruitment requires ligand binding by either RAR, RXR, or by both receptors in the above experiments. To assess ligand specificity of PCAF recruitment, synthetic retinoids selective for RAR (TT N PB) and RXR (SR 11237) were tested in a beads binding assay (Lehmann et al. 1992; Forman et al. 1995; Minucci et al. 1997). Both TTN PB and SR 11237 tested here have been shown to bind to the respective receptor within the heterodimer, although binding of only the RAR ligand leads to transcriptional activation from promoters carrying the RARE (Minucci et al. 1997). As shown in Figure $2 C$ and $D$, addition of both retinoids led to recruitment of PCAF as well as that of p300, although the levels of recruitment by these ligands appeared somewhat lower than those by 9-cis RA at doses tested (SR 11237, $10^{-6}$ and $10^{-5} \mathrm{M}$; TTN PB, $10^{-9}$ and $\left.10^{-8} \mathrm{M}\right)$. In agreement with the recruitment of PCAF and p300, histone acetylase activities also accumuI ated on the heterodimers bound to either ligand. Thus, ligand binding by either receptor allows the heterodimer to recruit PCAF and el icit histone acetylase activity.
Recombinant PCAF binds directly to the RXR-RAR heterodimer without requiring ligand

To determine whether PCAF can bind physically to the RXR-RAR heterodimer, recombinant PCAF (rPCAF) was tested for its ability to bind to the heterodimer-RARE complex. For this purpose, a beads binding assay very similar to those used above was employed, with the small modification that paramagnetic beads, rather than agarose beads were used, which gave improved specificity in rPCAF binding. Binding assays shown in Figure 3A were tested in conditions where molar ratios of rPCAF to heterodimer varied from $1: 60$ to $1: 40$. rPCAF readily bound to the heterodimer-RARE complex in a heterodimer-dose-dependent manner, both in the presence and absence of 9-cis RA, with occasional variability in binding levels. These results show that PCAF is capable of binding directly to the heterodimer-RARE complex.

PCAF binds directly to several members of the nuclear receptor family in a ligand-independent manner

To determine whether additional members of the nuclear receptor family are able to interact directly with PCAF, the PCAF-binding activities of several steroid re 
Figure 3. Binding of PCAF to various nuclear hormone receptors in vitro. (A) Direct binding of rPCAF to RXR-RAR heterodimers. rPCAF (2 pmoles, 200 ng) was incubated with increasing amounts of heterodimers $(0.5 \mu \mathrm{g}$, lanes 3,5 or $1 \mu \mathrm{g}$, lanes $4,6)$ bound to the RARE-conjugated beads in the presence $(+)$ or absence $(-)$ of $1 \mu \mathrm{m}$ 9-cis RA. Binding of rPCAF was detected by immunoblot analysis with anti-M2Flag antibody. (Lane 1) 20 ng of rPCAF as input; (lane 2) eluates from RARE-conjugated beads without receptor. (B) Binding of RAR $\beta$ to rPCAF. Binding of [ ${ }^{35}$ S]methionine-label ed RAR $\beta$ was tested with rPCAF immobilized to the $M 2$ antibody matrix or matrix alone (M2), GST beads, GSTACTR in the presence $(+)$ or absence $(-)$ of 1 м 9-cis RA. (Right) Radiolabeled receptor input (30\%) tested in B and C. (C) Binding of ${ }^{35}$ S-labeled ER $\alpha$ or GR $\alpha$ to rPCAF immobilized to the $M 2$ antibody matrix was tested in the presence $(+)$ or absence $(-)$ of $1 \mu \mathrm{M} \beta$-estradiol (for ER $\alpha$ ) or $1 \mu \mathrm{m}$ dexamethasone (for GR). (D) PCAF-receptor interactions detected by yeast two-hybrid assays. Y east strain $Y 190$ was transformed with indicated GAL4-fusion plasmids. The liquid $\beta$-gal assays were performed for the transformants, which were grown in the presence or absence of corresponding hormones (10 nM deoxycorticosterone for $\mathrm{GR}, 100 \mathrm{~nm} \beta$-estradiol for $\mathrm{ER}$, and $100 \mathrm{~nm}$ dihydrotestosterone for $\mathrm{AR}$ ). Results represent the average of three independent yeast transformants \pm S.D.

ceptors were determined by in vitro pull-down or yeast two-hybrid assays. Solution binding assays were carried out either in the presence or absence of $1 \mu \mathrm{m}$ receptor ligand with PPCAF protein immobilized on M 2 antibodyagarose beads and nuclear receptor proteins generated by in vitro transcription/translation in the presence of $\left[{ }^{35}\right.$ S]methionine. As shown in Figure $3 B$, in vitro-translated RAR $\beta$ is retained on the PCAF matrix but not on the $\mathrm{M} 2$ matrix al one, demonstrating that the interaction between RAR $\beta$ and PCAF is both direct and specific. Interestingly, binding of RAR $\beta$ to PCAF can be detected even under conditions in which the RAR $\beta$ ligand, 9-cis RA, is omitted from the reaction. This is in marked contrast to the interaction between RAR $\beta$ and the transcriptional coactivator, ACTR, which is shown to be dependent on the presence of ligand (Chen et al. 1997). When tested in the same protein-protein interaction assay, both ER $\alpha$ and GR display specific PCAF-binding activity that is similarly ligand independent. This is demonstrated in Figure 3C, in which both ER $\alpha$ and GR are retained on the PCAF matrix in both the presence and absence of their respective ligands. These results can be largely reproduced when the interactions are assayed in the yeast two-hybrid system (Fig. 3D). Assays were performed with theDN A-binding domain of GR, full-length $E R \alpha$, and the full-length AR. $\beta$-Gal activity was increased significantly in yeast cells transformed with the receptor constructs even in the absence of ligand (cf. lanes 2,3 , and 4 with lane 1). The slightly greater increase in $\beta$-gal activity noted for the ER $\alpha$ and AR following addition of respective ligands is likely attributable to ligand-induced transactivation activities of the ligandbinding domains. These results indicate that both retinoids and steroid receptors can interact directly with
PCAF in vitro, suggesting that this activity may be a general property of nuclear receptors. M oreover, results presented here distinguish PCAF from previously characterized receptor coactivators and corepressors whose receptor-binding activities are, instead, significantly modulated by the ligand-binding status of the receptor (for review, see Glass et al. 1997).

The role of corepressors in ligand-dependent recruitment of PCAF

Ligand-independent binding of $\mathrm{rPCAF}$ to the heterodimer above was contrary to the ligand-dependent recruitment of the endogenous PCAF observed in Figures 1 and 2. The dichotomy of ligand requirement found in these assays may suggest that PCAF binding to unliganded heterodi mers in vivo is prevented by a factor(s) present in the nucl ear extracts. Because corepressors such as SM RT and N-CoR (RIP13) bind to the unl iganded heterodimers and are dissociated from the heterodimer upon ligand binding (Chen et al. 1995; Horlein et al. 1995; Seol et al. 1996), it was attractive to postulate that corepressors may be involved in ligand-dependent PCAF binding. In experiments shown in Figure 4, we tested whether corepressors alter PCAF binding in vitro. As shown in Figure $4 A$, addition of the GST-SMRT fusion protein inhibited rPCAF binding to the heterodimer-RARE complex in the absence of ligand (lane 3). However, rPCAF binding was restored when 9-cis RA was added to the reaction (lane 4). As expected, SMRT readily bound to the heterodimer in the absence of ligand, and was released upon ligand addition. Addition of the control GST peptide did not affect rPCAF binding (lanes 1,2). Si milar ligand-induced restoration of rPCAF binding was observed with another 
A

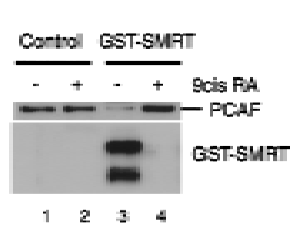

B

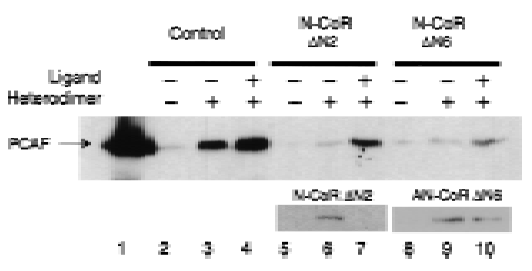

C

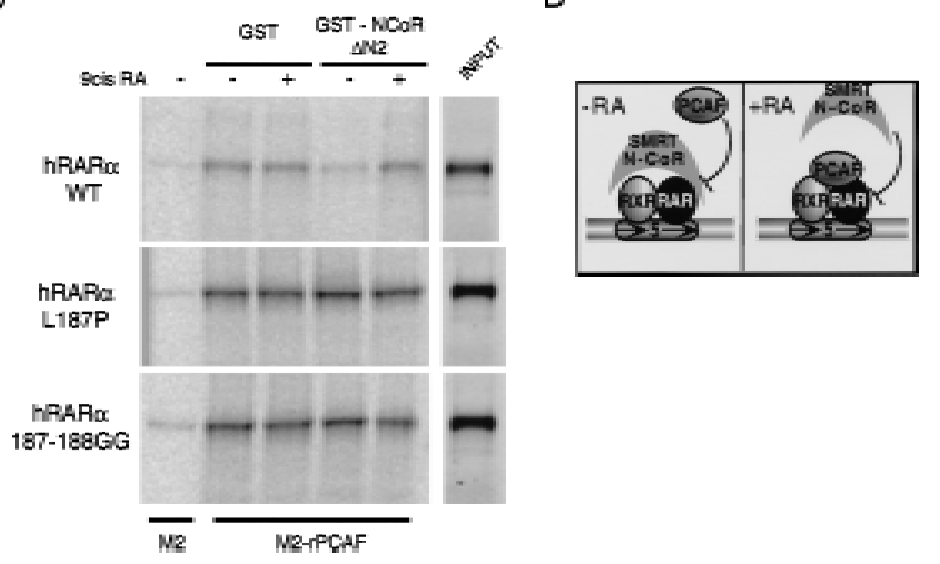

Figure 4. Corepressors enable ligand-dependent binding of PCAF to the RXR-RAR heterodimer in vitro. (A) The effect of SMRT. One microgram of DNA-bound RXR-RAR heterodimers was incubated with $200 \mathrm{ng}$ of rPCAF and $500 \mathrm{ng}$ of control GST (lanes 1,2) or GST-SMRT (lanes $3,4)$ in the presence or absence of $1 \mu \mathrm{M} 9$ cis RA. Binding of PCAF and GST-SMRT to the heterodimer was detected by antiM2 antibody and anti-SM RT antibody, respectively. (B) The effect of $\mathrm{N}-\mathrm{CoR}$. Binding assays were performed as in Fig. 5A, but with 500 ng of control GST (lane 2-4), GST-N-CoR $\Delta \mathrm{N} 2$ (lane 5-7), or GST-NCoR $\Delta N 6$ (lane 8-10) with (+) or without $(-)$ $1 \mu \mathrm{m}$ 9-cis RA. (Bottom) Binding of N-CoR was detected by anti-N-CoR antibody. (C) Ligand-independent PCAF binding to the hinge mutants of RAR $\alpha .{ }^{35} \mathrm{~S}$-Labeled, in vitro-translated hRAR $\alpha$ wild-type or hinge region mutants (L187P and 187-188GG) $\left(2 \times 10^{5} \mathrm{cpm}\right)$ were incubated with $2 \mu \mathrm{g}$ of immobilized rPCAF in the presence of GST or GST-N-CoR $\Delta \mathrm{N} 2$ and with $(+)$ or without $(\rightarrow 1 \mu \mathrm{M}$ 9-cis RA. (M 2) Binding of radiolabeled RARs to the $M 2$ beads without rPCAF; (INPUT) amounts of RARs $\left(2 \times 10^{4} \mathrm{cpm}\right)$ tested in each reaction. (D) Scheme for corepressor dissociation and PCAF binding. corepressor N-CoR (RIP13) (Fig. 4B). When incubated with the truncated GST -N -CoR $\Delta \mathrm{N} 2$ (RIP13 $\Delta \mathrm{N} 2$ ) without ligand, rPCAF failed to bind to the heterodimer, but binding was restored when 9-cis RA was added to the reaction (cf. lanes 6 and 7). This N-CoR was released from the heterodimer complex after ligand addition, as reported previously (Seol et al. 1996). When incubated with another construct, N-CoR $\Delta$ N 6 (RIP13 $\Delta$ N 6), which binds to an unliganded receptor but is not readily dissociated from the receptor upon ligand addition (Fig. 4B, Seol et al. 1996), only a small fraction of rPCAF bound to the complex even after ligand addition (cf. lanes 9 and $10)$.

Corepressors are shown to bind to the receptors through the hinge region of the ligand-binding domain (Horlein et al. 1995). To substantiate further the role for corepressors in PCAF binding, we constructed two RAR $\alpha$ mutants contai ning mutations in the hinge region (Horlein et al. 1995) for PCAF binding. These hRAR $\alpha$ mutants, L187P and 187-188GG, are unable to bind to $\mathrm{N}-\mathrm{CoR}$. In Figure 4C, binding of these mutants to immobilized rPCAF was tested in the presence of $\mathrm{N}-\mathrm{CoR}$ $\Delta \mathrm{N} 2$ and with and without 9-cis RA. While in the presence of GST-N-CoR, the wild-type RAR $\alpha$ bound to rPCAF in a ligand-dependent manner, both mutants bound to rPCAF irrespective of ligand addition. As expected, in the presence of the control GST, all three RAR $\alpha$ constructs bound to rPCAF even in the absence of ligand. Similar results were observed with SMRT (not shown). These results indicate that ligand-regulated association/dissociation of corepressor proteins controls PCAF binding to the heterodimer (Fig. 4D).

The RXR-RAR heterodimer binds to rPCAF independently of p300

p300 and CBP have been shown to interact with PCAF as well as with the RXR-RAR heterodimer (Chakravarti et al. 1996; Kamei et al. 1996; Y ang et al. 1996). Because PCAF and p300/CBP were both recruited to the heterodimer in Figures 1 and 2, it was of importance to assess whether rPCAF can bind to the heterodimer independently of p300 and/or CBP. It has been shown that p300 and CBP bind to receptors through their amino-terminal domain (Chakravarti et al. 1996; Kamei et al. 1996). On the other hand, PCAF appears to bind to p300 and CBP predominantly through the carboxy-terminal domain (Yang et al. 1996). In Figure 5A, we examined contributions of p300 to PCAF-receptor interaction by using a truncated p300, designated $\mathrm{N}-\mathrm{p} 300$, that retained the amino-terminal 670 amino acids required for binding to the heterodimer, but was devoid of the carboxy-terminal domain involved in interaction with PCAF. Experiments presented in Figure 5A were performed with relatively low heterodimer concentrations to minimize receptor excess conditions in which only PCAF or N-p300 might bind to a heterodimer. As shown in Figure 5A (lanes 1,2), $\mathrm{N}-\mathrm{p} 300$ bound to the heterodimer in the absence of 
A

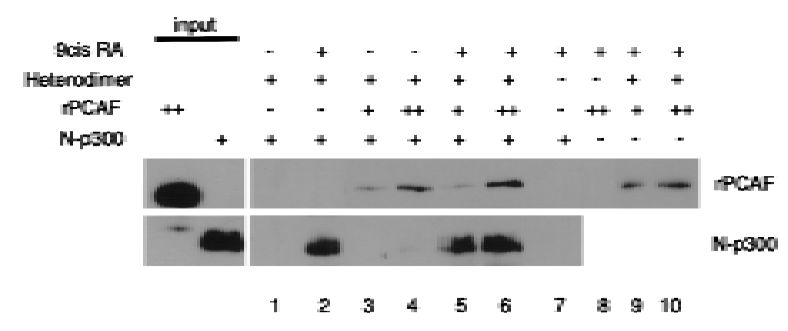

B

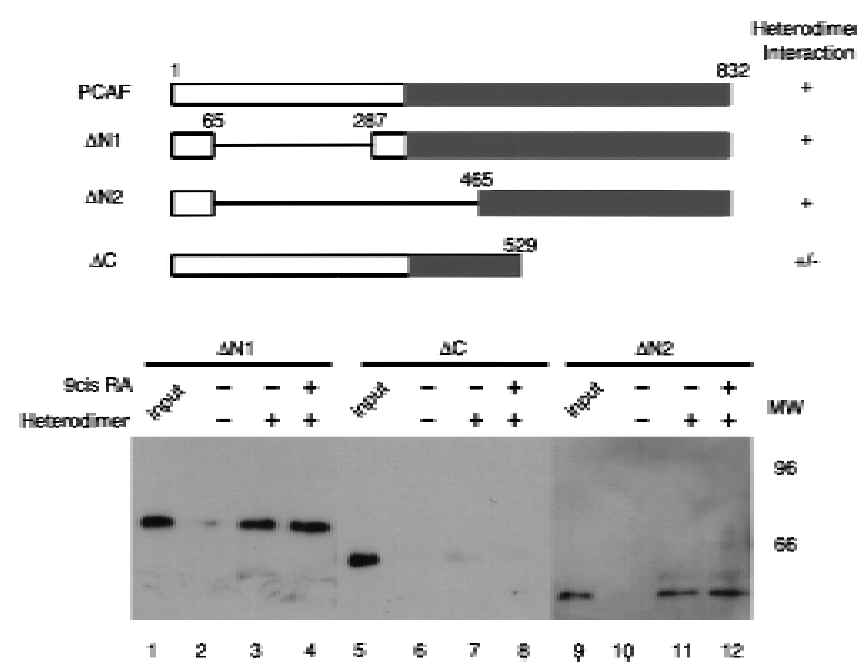

Figure 5. PCAF domain analysis and the relationship with p300. (A) Heterodimer-RARE complexes $(\sim 2$ pmoles) were incubated with 2 pmoles of recombinant $\mathrm{N}$-p300 (amino acids 1-670) al one (lanes 1,2) or al ong with $1(+)$ and $2(++)$ pmoles of PCAF (lane 3-6) in the presence $(+)$ or absence $(-)$ of $1 \mu \mathrm{M}$ 9-cis RA. (B) PCAF domain analysis: 2 pmoles of rPCAF lacking the carboxy-terminal domain $(\Delta C)$ or amino-terminal domain ( $\Delta \mathrm{N} 1$ and $\Delta \mathrm{N} 2$, top) were incubated with heterodimer-RARE complexes ( $1 \mu \mathrm{g}$ of heterodimer) in the presence $(+)$ or absence $(\rightarrow$ of $1 \mu \mathrm{M}$ 9-cis RA. Binding was detected with anti-PCAF antibody.

rPCAF, in a ligand-dependent fashion, as expected. Binding of $\mathrm{N}$-p300 to the heterodimer was unaffected by addition of rPCAF (lanes 1 and 2 vs. Ianes 5 and 6). Conversely, rPCAF bound to the heterodimer in the presence of $\mathrm{N}$-p300 in a dose-dependent manner (lanes 3,4), and addition of $\mathrm{N}-\mathrm{p} 300$ did not enhance or reduce PCAF binding (cf. lanes 3, 4, 5, and 6 vs. lanes 9 and 10). These data indicate that PCAF and N-p300 can bind to the heterodimer without interfering with each other.

\section{PCAF domain analysis}

Of the two domains present in PCAF, the carboxy-terminal domain from amino acid position 352 to 832 represents the region homologous to the yeast GCN 5 and contains histone acetylase activity (see diagram in Fig. 5B; $Y$ ang et al. 1996). The amino-terminal region, composed of amino acids 1-351, shares little homology with known genes, and its function has not been fully elucidated. To determine a region of PCAF involved in binding to the heterodimer, we examined truncated rPCAFs lacking either the amino-terminal or carboxy-terminal domain (Fig. 5B). Recombinant $\Delta \mathrm{N} 1$ or $\Delta \mathrm{N} 2$, lacking either the amino-terminal domain al one or the amino-terminal region plus the additional 113 amino acids of the carboxy-terminal region, bound to the heterodimerRARE complex, although binding of $\triangle N 2$ was slightly weaker than that of $\Delta \mathrm{N} 1$ and full-length PCAF. In contrast, $\Delta C$ showed little binding to the complex. As found in Figure 4, ligand had no effect on the binding activity of the truncated PCAF (see lane 3 vs. lane 4, lane 11 vs. Iane 12). These results indicate that the conserved carboxy- terminal domain is required for binding to the heterodimer-RARE complex.

The DNA-binding domain of receptors interacts with PCAF

$\mathrm{N}$ uclear receptors are composed of three domains, the amino-terminal domain, the DNA-binding domain, and the ligand-binding domain, each of which has a discrete function (see scheme in Fig. 6; Beato 1989; Tsai and O'M alley 1994; M angelsdorf and Evans 1995; Chambon 1996). The ligand-binding domain includes the conserved AF-2 region, critical for ligand-dependent transcriptional activation (Danielian et al. 1992; $\mathrm{N}$ agpal et al . 1992; Leng et al. 1995). The question addressed in this set of experiments was which domain of the receptor is required for PCAF binding. Binding of ${ }^{35} \mathrm{~S}$-labeled fulllength $\mathrm{RXR} \alpha, \mathrm{RAR} \beta$, or receptors containing various deletions (Fig. 6A) was tested with rPCAF immobilized to beads through anti-M 2 Flag antibody. ${ }^{35} \mathrm{~S}$-labeled fulllength RAR $\alpha$ and $R X R \beta$ both bound to immobilized rPCAF again in the presence and absence of ligand (for summary, see Fig. 6A). Deletion from both receptors of the conserved AF-2 domain ( $\mathrm{N}$ agpal et al. 1992; Leng et al. 1995), which was shown to be required for p300/CBP binding (Kamei et al . 1996), did not affect rPCAF binding (RXR $\beta$ AF-2 and RAR $\alpha 404$ in Fig. 6B). Similarly, a large deletion of the amino-terminal domain $(R X R \beta \Delta N)$ or of the ligand-binding domain from $\operatorname{RXR} \beta(\Delta \mathrm{LBD})$ did not affect PCAF binding. In addition, several carboxy-terminal del etions of RAR $\alpha(419,419 / \Delta \mathrm{Pst}, 404$ and 404/ $\Delta \mathrm{Pst})$ had no effect on rPCAF binding. In contrast, deletion of the DNA-binding domain from both receptors $(R X R \beta$ $\triangle D B D$ or RAR $\alpha \Delta N-D B D$ ) led to complete abrogation of 

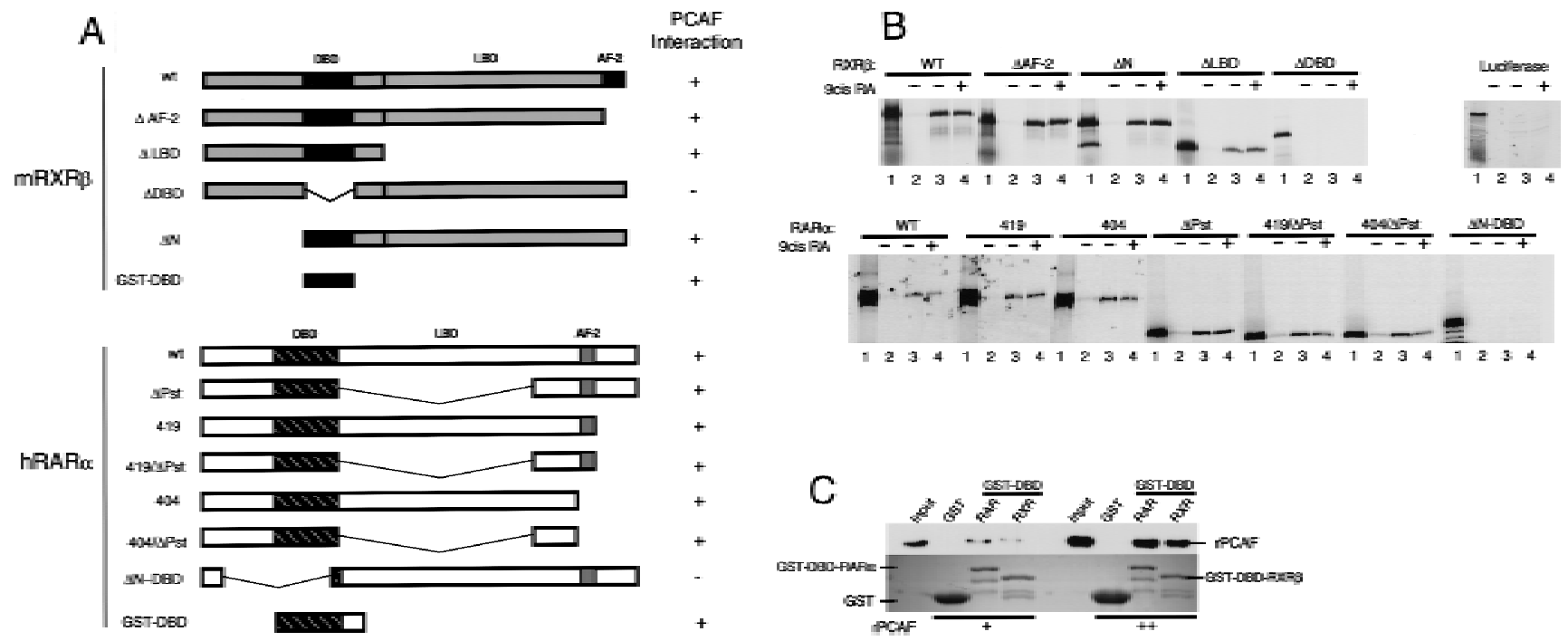

Figure 6. Receptor domain analysis. (A) Diagram of full-length and truncated RXR $\beta$ and RAR $\alpha$ and summary of PCAF binding (+, significant binding; -, no detectable binding). (B) ${ }^{35} \mathrm{~S}$-Labeled receptors were incubated with rPCAF bound to anti-M 2-Flag antibody conjugated to beads as in Fig. 4C. (Lane 1) Input ( $\left.2 \times 10^{4} \mathrm{cpm}\right)$; (lane 2) control M 2 beads without PCAF; (Ianes 3,4) M 2-rPCAF without $\left(\rightarrow\right.$ or with $(+) 1 \mu \mathrm{M}$ 9-cis RA, respectively. ${ }^{35}$ S-Label ed luciferase was tested as a negative control. (C) Control GST, GST-DBD from RAR $\beta$, or GST-DBD from RXR $\alpha$ (500 ng each) was incubated with rPCAF (+, $100 \mathrm{ng} ;++, 300 \mathrm{ng}$ ) and PCAF binding was detected with anti-PCAF antibody. (Bottom) Loading of the control GST peptide, GST-DBD of RAR $\alpha$, and GST-DBD of RXR $\beta$.

rPCAF binding. These results indicate that both RXR and RAR are capable of binding to PCAF, for which the intact DNA-binding domain is required. To evaluate further the significance of the DNA-binding domain in PCAF binding, we tested whether a GST fusion containing the DNA-binding domain of RXR $\beta$ or RAR $\alpha$ (Fig. 6C) can bind to rPCAF. Pull-down data in Figure $6 C$ confirm that the DBD peptides of both RXR $\beta$ and RAR $\alpha$ bind to rPCAF at simlar high levels, while the control GST peptides fail to bind to rPCAF.

\section{PCAF potentiates transcription}

from retinoid-responsive promoters

To test the functional significance of PCAF recruitment by the RXR-RAR heterodimer, reporter assays were carried out with $\mathrm{NIH}-3 \mathrm{~T} 3$ cells transiently transfected with a PCAF expression vector and a luciferase gene fused to a thymidine kinase (TK) promoter and two copies of the RARE (DR-5) (Minucci et al. 1997; Fig. 7A). Addition of RA led to a modest increase in luciferase activity in the absence of PCAF. The relatively low reporter activity is likely to be attributable to the low levels of endogenous receptors expressed in NIH-3T3 cells. Significantly, transfection of the PCAF vector led to a dose-dependent enhancement in RA-induced reporter activity. When RAR and RXR expression vectors were cotransfected into N IH-3T 3 cells (Fig. 7B), RA-dependent I uci ferase activity was increased further. When cells were cotransfected with PCAF al ong with the receptor vectors, RAinduced luciferase activity was even more enhanced in a PCAF-dose-dependent manner. PCAF transfection had little effect on basal promoter activity, as measured without RA treatment (solvent in Fig. 7), indicating that PCAF potentiates ligand-dependent transcription. To evaluate a domain within PCAF that is involved in enhancing promoter activity, two PCAF deletion mutants, $\Delta C$ and $\Delta N 2$, tested in Figure 5, were examined in reporter assays. As seen in Figure 7B, these del etions gave a modest enhancement in promoter activity, only about half the enhancement seen by the intact PCAF, indicating that both domains of PCAF play a role in enhancing transcription. To eval uate whether PCAF enhances Iigand-dependent promoter activity through its histone acetyl ase activity, we tested two additional del etion constructs in which the recently identified catalytic domain of PCAF was deleted ( $\triangle$ HAT 1 and $\triangle$ HAT2, see location of deletions in Materials and M ethods). Histone acetylase activity was found to be completely abrogated in these deletion constructs in vitro (data not shown). As shown in Figure $7 \mathrm{C}, \triangle \mathrm{HAT} 1$ and $\triangle \mathrm{HAT} 2$, similar to $\triangle \mathrm{C}$ and $\triangle N 2$, failed to give full enhancement in promoter activity attained by the intact PCAF. These results support the idea that PCAF potentiates retinoid-dependent transcription at least partly through its histone acetylase activity. Immunoblot analysis performed with transfected cells (Fig. 7D) showed that exogenous PCAF was expressed in a dose-dependent manner, while the expression of the endogenous p300 remained unchanged. In addition, data in Figure 7D (right) verify that transfection of del etion constructs resulted in expression of truncated PCAFs of the expected sizes.

To ascertain whether PCAF potentiates ligand-dependent transcription in a chromatin environment similar to that of a native gene, we measured promoter activity of the RARE-Tk-Iuciferase gene (the same reporter as 
Blanco et al.

A

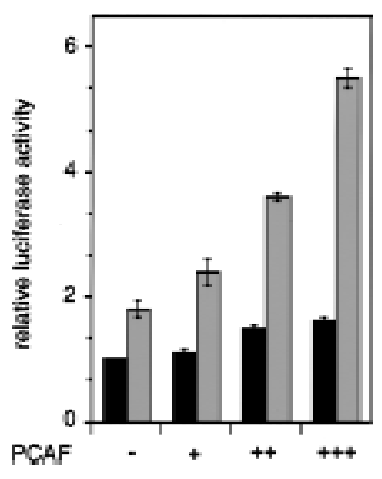

D

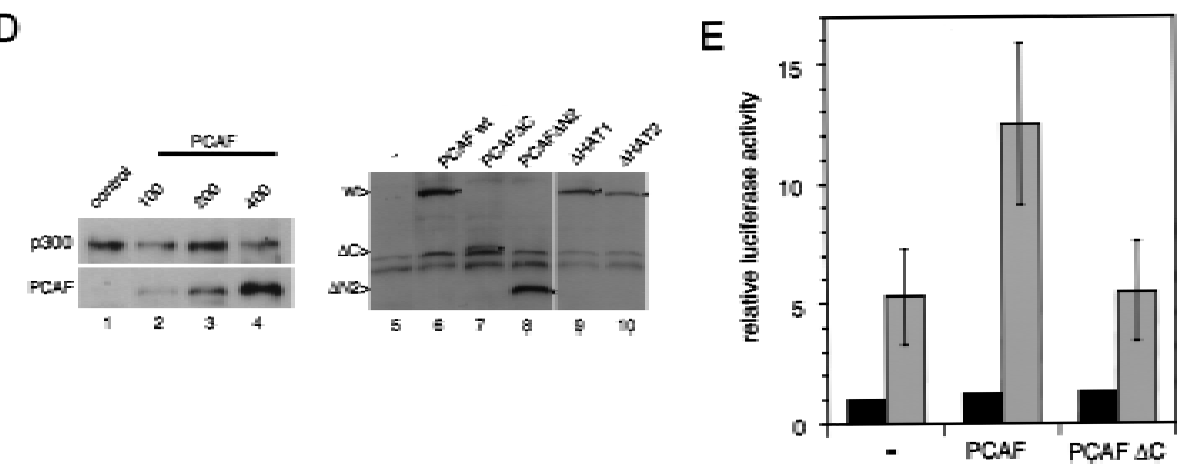

B

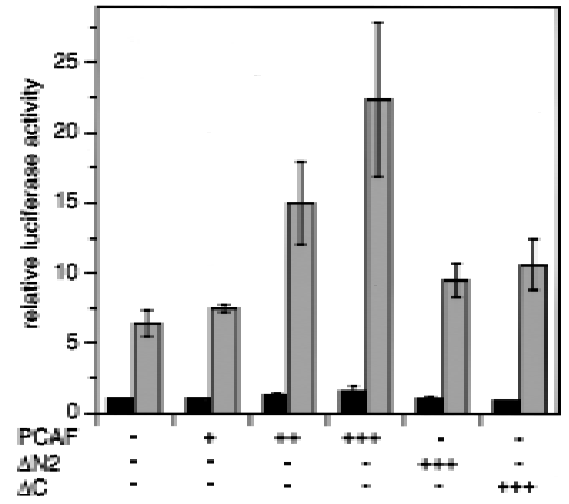

$\mathrm{C}$

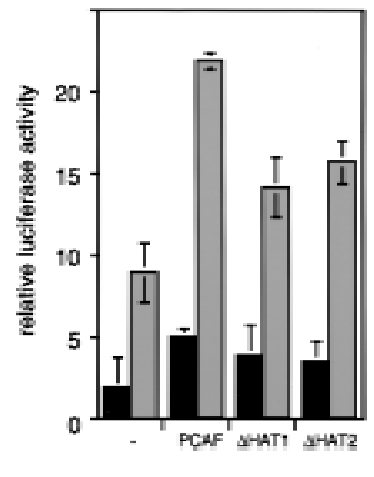

Figure 7. Enhancement of retinoid-dependent promoter activity by transfected PCAF. (A) NIH-3T $3\left(1.5 \times 10^{5}\right)$ cells were cotransfected with the RARE-Tk-luciferase reporter and pcx-PCAF (+, 50 ng; ++, $200 \mathrm{ng}$; or,$+++ 400 \mathrm{ng})$, and luciferase activity was measured following $24 \mathrm{hr}$ of $1 \mu \mathrm{M}$ all trans-RA treatment. Shaded and solid bars represent luciferase activity with and without RA, respectively. Values represent the average of triplicate cultures \pm S.D. (B) Transfection was performed as in A but with additional expression vectors for RXR $\beta$ and RAR $\alpha$ (40 ng of each), and with pCX-PCAF (+, $50 \mathrm{ng} ;++, 200 \mathrm{ng}$; and +H, $400 \mathrm{ng}$ ) or pCX-PCAF mutants ( $\triangle \mathrm{N} 2$ and $\Delta \mathrm{C}$, $400 \mathrm{ng}$ ). Values represent the average of four independent assays \pm S.D. (C) Transfection was performed as in $B$, but with $400 \mathrm{ng}$ each of control (pcx), PCAF, or HAT deletions ( $\triangle$ HAT1 and $\triangle$ HAT2). Values represent the average of triplicates \pm s.D. (D) Detection of transfected PCAF and endogenous p300. N uclear extracts from $6 \times 10^{5} \mathrm{NIH}-3 \mathrm{~T} 3$ cells transfected with indicated amounts (ng) of pcx-PCAF or deletion PCAFs tested in B and C were immunoblotted with anti-M 2-Flag antibody to detect PCAF or with anti-p300 antibody. Asterisks indicate the position of the wild-type or mutant PCAFs. (E) Pool of NIH-3T3 cells stably transfected with the RARE-Tk-Iuciferase reporter was transiently transfected with pcx-PCAF or pcx- $\Delta C$ plus an IL-2R vector, and treated with $1 \mu \mathrm{M}$ all trans-RA. Cells were sorted by anti-IL-2R antibody panning and luciferase activity was measured as in $A$. Values represent the average of triplicates \pm S.D.

above) that had been stably transfected into NIH-3T 3 cells (Fig. 7E). Then, these cells were transiently transfected with expression vectors for PCAF and IL-2R, treated with RA for $24 \mathrm{hr}$, and sorted for transfection by IL-2R expression. As seen in Figure 7E, transfection of PCAF resulted in a modest but reproducible increase in RA-dependent reporter activity with little effect on basal promoter activity. However, transfection of $\Delta \mathrm{C}$ gave almost no increase in luciferase activity. Thus, ectopic expression of PCAF enhances RA-mediated transcription from a transiently transfected promoter as well as a promoter stably integrated into the cells.

\section{Discussion}

We show that upon ligand addition, the RXR-RAR heterodimer complexed to RARE-conjugated beads effi- ciently recruits the endogenous PCAF present in the mammal ian cell nuclear extracts. While the PCAF association is direct, and apparently independent of CBP, in vivo, it appears to be part of a larger complex, as the human homolog of ADA2 was also found to bind to the liganded heterodimer (Fig. 1B). The ADA2 complex may be a conserved feature in eukaryotes as yeast GCN 5 also complexes with ADA2 and ADA3 (Horiuchi et al. 1995; Berger et al. 1996; Candau et al. 1996). A critical role for PCAF is supported further by the recent demonstration that it also associates with nuclear cofactors, such as p300, CBP, and ACTR (Y ang et al. 1996; Chen et al. 1997). Each of these cofactors is shown to have histone acetylase activity itself (Bannister et al. 1996; Ogryzko et al. 1996), which we expect to further potentiate acetylation of histones near or at the site of transcription. 


\section{Ligand specificity}

Results in Figure 2 show that the synthetic retinoids selective for RXR or RAR are both capable of recruiting PCAF and cause accumulation of histone acetylase activity. These results are interesting in light of differential activities that the two ligands exert in transcription: Previous work from a number of groups showed that while the RAR ligand alone activates transcription, the RXR ligand al one does not (Lehmann et al . 1992; Kurokawa et al. 1994; Forman et al. 1995; Minucci et al. 1997). The RXR ligand, however, is capable of enhancing transcripti on when added al ong with an RA R ligand (Forman et al. 1995; $\mathrm{M}$ inucci et al. 1997). These and the present finding that the RXR ligand is functional in recruiting PCAF appear to support the view that RXR in the heterodimer plays an active role in transcription, rather than serving as a silent partner of the RAR.

The interaction between PCAF and nuclear receptors is direct

Direct interaction of PCAF with multiple receptors, such as RXR-RAR heterodimers, $E R \alpha, A R$, and GR suggests that its recruitment may be a universal property of the nuclear hormone receptors. In combination with previous studies, our data suggest that PCAF binds di rectly to both nuclear receptors and p300/CBP (Chakravarti et al. 1996; Yang et al . 1996). Furthermore, our data suggest that these interactions may occur sequentially with PCAF first associating with receptors followed by interaction with p300/CBP. This is consistent with the observation that PCAF binds more efficiently to the heterodimer-RARE complex than does p300/CBP and that the acetylase profile of the complex is typical of PCAF but not p300/CBP. Therefore, we suggest that ligand binding stimulates independent recruitment of both PCAF and p300/CBP to the heterodimers, which is then followed by a cooperative, multipoint interaction between these molecules (Janknecht and Hunter 1996; Smith et al. 1996). Although not supported by our data, the possibility that PCAF or a portion of the PCAF pool is sequestered by coactivators prior to ligand addition cannnot be excluded.
Analyses of deletion constructs from both $R X R$ and RAR (Fig. 5) revealed that the DN A-binding domain has a critical role in binding to PCAF. These results, however, do not rule out the possibility that other regions of the receptors have auxiliary roles. The observation that PCAF clearly interacts with the DNA-bound heterodimer provides an explanation for previous suggestions for an activator function closely linked to the DN A-binding domain (Zaret and Yamamoto 1984).

\section{A possible role for corepressors}

We found that corepressors from the N-C oR-SM RT family inhibit binding of rPCAF to the heterodimer in the absence of ligand, but that this binding is restored upon addition of ligand, concomitant with repressor release (Fig. 5A,B). These results suggest that corepressors, by virtue of their dissociation from the receptor, confer ligand dependence on PCAF binding. It has been shown that N-CoR and SM RT bind to the hinge region of receptors (Chen and Evans 1995; Horlein 1995). Because the hinge region present in the ligand-binding domain is only 30 amino acids away from the DN A-binding domain, corepressors could either cause a steric block of PCAF binding or alternatively induce a local conformational change that precludes PCAF binding. Adding to this passive regulation of activity exclusion, corepressors have recently been shown to be associated with the histone deacetylase HDAC-1 and $\mathrm{mSin} 3$, which are thought to establish transcriptional repression via modification of chromatin (Alland et al. 1997; Heinzel et al. 1997; $\mathrm{N}$ agy et al . 1997). A model depicting how ligand reverses this process in two steps is shown in Figure 8. First, ligand promotes the dissociation of the repressor complex, which in turn enables the second step of PCAF recruitment. Like the repressors, PCAF itself also functions in at least two ways. First, as a histone acetylase it has the direct capacity to modify chromatin to reverse repression. Second, via its p300/CBP- and SRC-interaction domains, it serves to recruit additional activators.

In summary, this work reveals a new dynamic interplay of coactivators and corepressors and suggests a potential mechanistic linkage between these two pro-
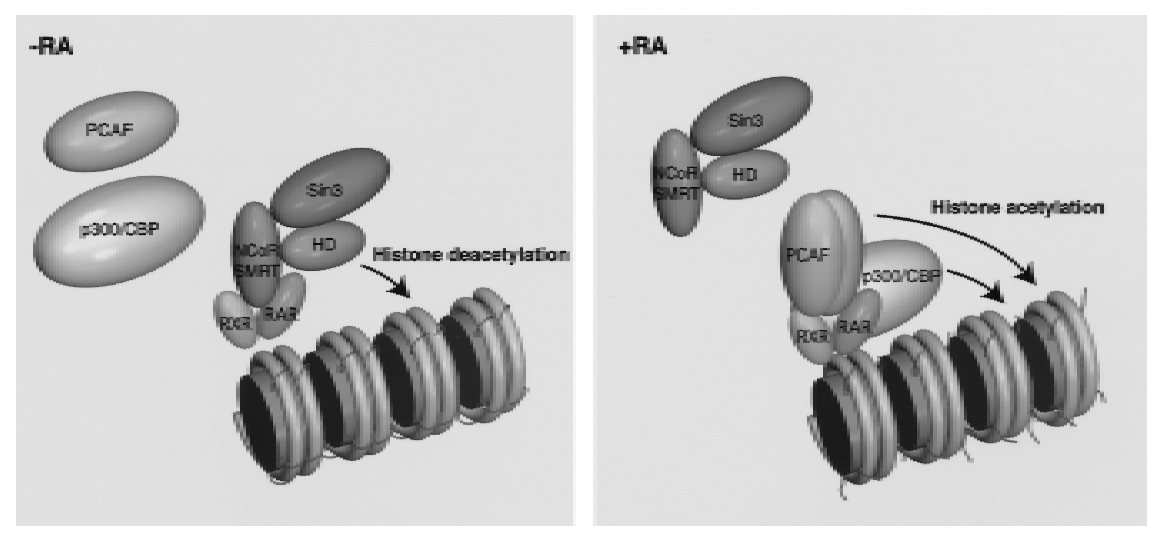

Figure 8. A model for PCAF recruitment: Coupling with the ligand-induced disengagement of the histone deacetylase-corepressor complex. Prior to ligand binding, the heterodimer is associated with histone deacetylases complexed with corepressor-Sin3, providing a repressive chromatin environment. Ligand binding may rel ease the histone deacetylase-Sin3-corepressor complex and allow recruitment of PCAF and p300/CBP, facilitating the generation of transcriptionally active chromatin. 
cesses. It reveals an intriguing way in which ligand can control functions outsi de the ligand-binding domain and suggests coactivation may occur in stages with PCAF playing a more central role in hormonal signaling than suggested previously. As PCAF and p300/CBP are part of many transcription factor complexes, it will be especially interesting to know whether the central role suggested for PCAF with nuclear receptors extends to other signaling pathways.

\section{Materials and methods}

Cloning and purification of recombinant receptors expressed from baculovirus vectors

Complementary oligonucleotides coding for a translation start site followed by eight histidines and an enterokinase recognition sequence were inserted into the Bgl II-N otl site of pVL1392 (Invitrogen), and the resulting construct was used as a modified baculovirus transfer vector. CDNAs for mouse RXR $\beta$ and human RAR $\beta$ were cloned in-frame into the $\mathrm{Notl-BamHI}$ sites of the vector. Sf 9 cells were grown in spinner flasks at $27^{\circ} \mathrm{C}$ with Grace's insect media containing 10\% FBS. Transfer vectors were cotransfected with the linearized baculoGold DNA (PharM ingen) into Sf9 insect cells. Recombinant viruses were cloned by use of a conventional plaque assay and amplified to an optimal titer level. For large-scale production of recombinant receptors, Sf9 cells $\left(1.5 \times 10^{8}\right.$ cells) were infected with recombinant viruses at a m.o.i. of 1 and maintained in culture for 2.5 days. Cells were collected by centrifugation, lysed with $\mathrm{BC}$ buffer (20 mM HEPES at pH 7.9, 10\% glycerol, 0.5 mm EDTA) containing $100 \mathrm{~mm} \mathrm{KCl}$ supplemented with $1 \%$ Triton X-100, and lysates were clarified by centrifugation. Recombinant receptors were purified by a two-step procedure: Whole-cell extracts $\left(1.5 \times 10^{8}\right.$ cells) were first chromatographed through a heparin column (Fast Flow, Pharmacia), and receptors were eluted with $\mathrm{BC}$ buffer containing $400 \mathrm{mM} \mathrm{KCl}$. The el uates were then incubated with the $\mathrm{Ni}^{2+}-\mathrm{NTA}$ resin (Qiagen; $500 \mu \mathrm{l}$ of packed resin for each receptor preparation), washed with $\mathrm{BC}$ buffer with $100 \mathrm{mM} \mathrm{KCl}$, and el uted with the same buffer containing $100 \mathrm{~mm}$ imidazole. The procedure yiel ded between 300 and $500 \mu \mathrm{g}$ of recombinant receptors with a purity of $90 \%$ as estimated by SDS-PAGE and Coomassie blue staining. Each receptor preparation was tested for heterodimer formation, DNAbinding activity by use of RARE-containing oligomers (DR-5), and ligand-binding activity by use of all-trans RA and 9-cis RA as described (M inucci et al. 1997).

\section{Binding of cellular PCAF to the heterodimer-DNA complex}

A 160-bp DNA fragment containing two copies of the RARE (DR-5) from the RAR $\beta 2$ promoter (M inucci et al. 1997) labeled with biotin at the $5^{\prime}$ end was prepared by PCR and conjugated to streptavidin-agarose beads (Pierce). A total of 1-3 $\mu \mathrm{g}$ of RXR $\beta$ and RAR $\beta$ prepared as described above was bound to 30 pmoles of RARE in $45 \mu \mathrm{l}$ of beads equilibrated in BC buffer containing $50 \mathrm{~mm} \mathrm{KCl}$. Binding of receptors to the RARE-conjugated beads was specific for the RARE as they did not bind to DNA fragments from an unrelated interferon-responsive promoter conjugated to beads and as receptor binding to the RARE beads was efficiently competed by excess free RARE, but not control oligomers of unrelated specificity. $\mathrm{N}$ uclear extracts from $\mathrm{N}$ amal wa human B cells were prepared by the described method (Luo et al . 1992). The heterodimer-RARE complexes bound to the agarose beads $(45 \mu \mathrm{l})$ were incubated with $3 \mathrm{mg}$ of the nuclear extracts equilibrated in $\mathrm{BC}$ buffer containing $100 \mathrm{~mm} \mathrm{KCl}$ and washed with the same buffer containing $0.1 \%$ Triton X-100. Bound materials were eluted with $\mathrm{BC}$ buffer containing $500 \mathrm{mM} \mathrm{KCl}$. Eluted proteins $(\sim 30 \mu \mathrm{g})$ were then resolved on $10 \%$ SDS-polyacrylamide gels and subjected to immunobl ot analysis with primary antibodies (below), peroxidase-labeled secondary antibodies, and the ECL reagents (Amersham). Rabbit anti-PCAF antibody and monoclonal anti-RXR $\beta$ were described previously (M arks et al. 1992; Y ang et al. 1996). Rabbit anti-human ADA2 antibody was raised against a bacterially expressed recombinant ADA2, and its specificity was confirmed by immunoprecipitation assays. Polyclonal antibodies to $\mathrm{p} 300$ and CBP were gifts from Drs. H. Serizawa and R.G. Roeder, respectively. Antibodies to YY 1 or M2-Flag were purchased from Santa Cruz or Eastman Kodak, respectively. Eluted materials ( $\sim 3 \mu \mathrm{g}$ of proteins) were tested for histone acetylase activity for core histones as described (Yang et al. 1996; Ogryzko et al. 1996).

Binding of rPCAF, rN-p300, and rSMRT/rN-CoR (RIP13) to the heterodimer-RARE complex

Full-length rPCAF containing a Flag tag was described previously (Yang et al. 1996). rPCAF $\Delta \mathrm{N} 1$ and $\Delta \mathrm{N} 2$ used in Figure 5 were prepared by site-directed mutagenesis according to standard techniques. rPCAF $\Delta C$ was prepared by digestion of fulllength PCAF with Pstl followed by religation. These truncated rPCAFs were expressed in a baculovirus vector and purified by affinity chromatography (Yang et al. 1996). Briefly, whole-cell extracts were prepared from Sf9 cells infected with recombinant viruses in a BC buffer containing $5 \mathrm{~mm} \mathrm{M} \mathrm{gCl} 2$ and $500 \mathrm{mM} \mathrm{KCl}$. Ten microliters of each extract was incubated with agarose beads bound to anti-M 2-Flag antibody (Kodak) at $4^{\circ} \mathrm{C}$ for $2 \mathrm{hr}$ with rotation. After washing with the same buffer, rPCAFs were eluted following addition of the M2-Flag peptide at $0.2 \mathrm{mg} / \mathrm{ml}$. The recombinant, truncated p300 containing the Flag tag, $\mathrm{rN}$ p300 was described previously (Ogryzko et al. 1996). To test their binding to receptors, rPCAFs or rN-p300 were incubated with rRXR and rRAR in $200 \mu \mathrm{l}$ of BC buffer containing $100 \mathrm{~mm}$ $\mathrm{N} \mathrm{aCl}$ for 30 min on ice, and then mixed with RARE-conjugated streptavidin paramagnetic beads (Dynabeads M-280, Dynal). Reactions were allowed to stand at $4^{\circ} \mathrm{C}$ for $15 \mathrm{~min}$, and then washed 3 times with the BC buffer with $100 \mathrm{~mm} \mathrm{NaCl}, 0.01 \%$ Triton X-100. Bound materials were eluted with $\mathrm{BC}$ buffer containing $1 \mathrm{M} \mathrm{N} \mathrm{aCl}$, and eluates were immunoblotted as above.

Recombinant N-CoR, RIP13 $\Delta \mathrm{N} 2$, and RIP13 $\mathrm{N} 6$ cloned in a GST vector (a kind gift from D. Moore) were prepared as described previously (Seol et al. 1996). GST-SMRT was described previously (Chen and Evans 1995). Bacterial extracts containing $\mathrm{rN}-\mathrm{COR}$ or the control GST polypeptides were mixed with rPCAF and the heterodimer-RARE complexes in $200 \mu \mathrm{l}$ of BC buffer containing $100 \mathrm{~mm} \mathrm{NaCl}, 0.01 \%$ Triton $X-100$ at $4^{\circ} \mathrm{C}$ for $30 \mathrm{~min}$, washed with the same buffer, and bound materials were analyzed by immunoblot assays as above.

\section{Domain analysis}

$\operatorname{mRXR} \beta$ and $h R A R \alpha$ and some of their del etions were described previously (Marks et al. 1992; Tate et al. 1994). Additional deletions were constructed from hRAR $\alpha$ in the pSG5 plasmid (pSG5-RAR $\alpha$ ) by digestion with Pstl and religation ( $\Delta 145-343)$. RAR $\alpha \Delta N-D B D(\Delta 19-135)$ was constructed by digestion of pSG5-RAR $\alpha$ with Acc65I and BstEll followed by an end-fill reaction and religation. Two hRAR $\alpha$ mutants, L187P and 187188GG, described in Horlein et al. (1995), were constructed by use of a standard site-directed mutagenesis protocol. Oligonucleotides 5'-GAGGTGGGGGAGCCCATTGAGAAGGTG- 
$3^{\prime}$ and $5^{\prime}$-CGCCGGAGGTGGGGGAGGGCGGTGAGAAGGTGCGTAAAGC-3' were used for hRAR $\alpha$ L187P and RAR $\alpha$ 178-188GG, respectively.

Receptors were in vitro translated and label ed with ${ }^{35} \mathrm{~S}$ by use of a TnT kit (Promega). Radiolabeled receptors $\left(2 \times 10^{5} \mathrm{cpm}\right)$ were incubated with rPCAF bound to anti-M 2 Flag antibodyconjugated beads in $100 \mu \mathrm{l}$ of BC buffer containing $100 \mathrm{~mm} \mathrm{KCl}$ and $0.1 \% \mathrm{NP}-40$ at $4^{\circ} \mathrm{C}$ for $1 \mathrm{hr}$, and washed 3 times with the same buffer. Eluted materials were electrophoresed in $10 \%$ SDS-PAGE and signals detected by radioautography. A GST fusion of the RXR $\beta$ DN A-binding domain (DBD) was constructed by in frame insertion of a PCR fragment corresponding to the sequence from amino acid position 79 to 156 into the EcoRISmal site of pGEX-4T1 vector (Pharmacia). A GST fusion of RAR $\alpha$ DBD was constructed by insertion of a PCR fragment corresponding to amino acids 85-189 into the EcoRI-N otl of the same vector. For GST pull-down assays, the GST-RAR DBD, GST-RXR DBD, and control GST polypeptides $(0.5 \mu \mathrm{g})$ were conjugated to glutathione-Sepharose $4 \mathrm{~B}$ beads, equilibrated in $\mathrm{BC}$ buffer containing $100 \mathrm{~mm} \mathrm{~N} \mathrm{aCl}, 0.01 \%$ Triton $\mathrm{X}-100$, and incubated with $300 \mathrm{ng}$ of $\mathrm{rPCAF}$ at $4^{\circ} \mathrm{C}$ for $1 \mathrm{hr}$. Beads were washed three times and eluted with buffer containing $10 \mathrm{~mm}$ reduced glutathione, $50 \mathrm{~mm}$ Tris- $\mathrm{HCl}(\mathrm{pH}$ 8.0). Eluted materials were analyzed by immunobl ot assays with anti-PCAF antibody.

\section{Transfection and reporter assays}

A mammalian expression vector for a Flag-tagged PCAF (pcxPCAF) was described previously ( $Y$ ang et al. 1996). $\Delta \mathrm{N} 2$ and $\Delta C$ PCAF used in Figure 7 were cloned into the pcx vector. PCAF constructs containing deletions in the catalytic domain were prepared by deletion of DN A sequences corresponding to amino acid positions 579-608 ( $\triangle$ HAT 1 ) or positions 609-624 ( $\triangle$ HAT2) and cloned into the pcx vector. The loss of histone acetylase activity in these mutants was confirmed by in vitro histone acetylase assays as above. The RARE-Tk luciferase reporter with two copies of the RARE (DR-5, the same RARE as that used in the binding assays) and pSG5-RAR $\alpha$ and pSG5-RXR $\beta$ used as expression vectors were described previously (M inucci et al. 1997). NIH-3T 3 cells were grown in Dulbecco's modified Eagle's medium supplemented with $10 \%$ FBS. For transient transfection, NIH-3T 3 cells $\left(1.5 \times 10^{5}\right.$ cells per well in a 24-well plate) were seeded the day before transfection. Cells were incubated with a mixture of DNA and the lipofectamine reagents (GIBCO-BRL) for 4-6 hr. The DN A mixture (a total of $550 \mathrm{ng}$ ) contained $0.1 \mu \mathrm{g}$ of the reporter, 40 ng of PSG5-RXR and PSG 5RAR, and up to 400 ng of pcX-PCAF or mutant PCAFs and the pcx to adjust a total amount of DNA. Cells were then washed, fed with complete medium containing all-trans-RA ( $1 \mu \mathrm{m}$, Sigma) or solvent (ethanol), and incubated for an additional 24 hr. Luciferase activity was normalized by protein concentrations. Immunoblot analysis was performed with nuclear extracts prepared from transfected cells ( $20 \mu \mathrm{g}$ of protein) using anti-M 2-Flag antibody and anti-p300 antibody. For stable transfection, $1.2 \times 10^{6} \mathrm{NIH}-3 \mathrm{~T} 3$ cells were transfected with the RARE-TK-Iuciferase reporter as described above and the pSVneo plasmid at a 10:1 ratio, and sel ected in the presence of G 418 $(400 \mu \mathrm{g} / \mathrm{ml})$ for 2 weeks. A pool of G418-resistant cells was transiently transfected $\left(6 \times 10^{6}\right.$ cells/well) with up to $2 \mu \mathrm{g}$ of pCX-PCAF and $200 \mathrm{ng}$ of pCX-IL2-R (Yang et al. 1996). After treatment with RA ( $1 \mu \mathrm{M})$ for $24 \mathrm{hr}$, cells were sorted by panning with anti-IL-2R antibody (Yang et al. 1996), and luciferase activity was assayed with an equal number of sorted cells.

\section{Acknowledgments}

We thank Drs. V.V. Ogryzko, D.D. Moore, and N. Bhat- tacharyya for the gift of constructs and discussions, M s. X. Zhou for nuclear extract preparations and Ms. J. Boll for secretarial help. K.K.W. is a fellow of the Leukemia Society of America. H.C. is a fellow of the American Cancer Society. R.M.E. is an Investigator of the Howard Medical Institute at the Salk Institute of Biological Studies. This work was supported in part by NIH grant 26444 (RME).

The publication costs of this article were defrayed in part by payment of page charges. This article must therefore be hereby marked "advertisement" in accordance with 18 USC section 1734 solely to indicate this fact.

\section{Note}

During the revision of this paper, Korzus et al . (1998) published a paper describing the interaction of PCAF and nuclear receptors.

\section{References}

Alland, L., R. Muhle, H. Hou Jr, J. Potes, L. Chin, N. SchreiberAgus, and R.A. DePinho. 1997. Role for N-CoR and histone deacetylase in Sin3-mediated transcriptional repression. Nature 387: 49-55.

Bannister, A.J. and T. Kouzarides. 1996. The CBP coactivator is a histone acetyltransferase. N ature 384: 641-643.

Beato, M. 1989. Gene regulation by steroid hormones. Cell 56: 335-344.

Berger, S.L., B. Pina, N. Silverman, G.A. M arcus, J. A gapite, J.L. Regier, S.J. Triezenberg, and L. Guarente. 1992. Genetic isoIation of ADA2: A potential transcriptional adaptor required for function of certain acidic activation domains. Cell 70: 251-265.

Blanco, J.C.G., I.-M . Wang, S.-Y. T sai, M.-J. Tsai, B.W. O'M alley, P.W. Jurutka, M.R. Haussler, and K. Ozato. 1995. Transcription factor TFIIB and the vitamin D receptor cooperatively activate ligand-dependent transcription. Proc. Natl. Acad. Sci. 92: 1535-1539.

Brownell, J.E. and C.D. Allis. 1996. Special HATs for special occasions: Linking histone acetylation to chromatin assembly and gene activation. Curr. O pin. Genet. Dev. 6: 176-184.

Brownell, J.E., J. Zhou, T. Ranalli, R. Kobayashi, D.G. Edmondson, S.Y. Roth, and C.D. Allis. 1996. Tetrahymena histone acetyltransferase A: A homolog to yeast Gcn5p linking histone acetylation to gene activation. Cell 84: 843-851.

Bustin, M., D.A. Lehn, and D. Landsman. 1990. Structural features of the HMG chromosomal proteins and their genes. Biochim. Biophys. Acta. 1049: 231-243.

Candau, R., P.A. Moore, L. Wang, N. Barlev, C.Y. Ying, C.A Rosen, and S.L. Berger. 1996. Identification of human proteins functionally conserved with the yeast putative adaptors ADA2 and GCN 5. Mol. Cell. Biol. 16: 593-602.

Chakravarti, D., V.J. LaM orte, M.C. N elson, T. N akajima, I.G. Schulman, H. Juguilon, M. Montminy, and R.M. Evans. 1996. Role of CBP/p300 in nuclear receptor signalling. Nature 383: 99-103.

Chambon, P. 1996. A decade of molecular biology of retinoic acid receptors. FASEB J. 10: 940-954.

Chen, H., R.J. Lin, R.L. Schiltz, D. Chakravarti, A. N ash, L. N agy, M.L. Privalsky, Y. N akatani, and R.M. Evans. 1997. $\mathrm{N}$ uclear receptor coactivator ACTR is a novel histone acetyltransferase and forms a multimeric activation complex with P/CAF and CBP/p300. Cell 90: 569-580.

Chen, J.D. and R.M. Evans. 1995. A transcriptional co-repressor that interacts with nuclear hormone receptors. Nature 
377: 454-457.

Danielian, P.S., R. White, J.A. Lees, and M.G. Parker. 1992. Identification of a conserved region required for hormone dependent transcriptional activation by steroid hormone receptors. EMBO J. 11: 1025-1033.

Fondell, J.D., F. Brunel, K. Hisatake, and R.G. Roeder. 1996. Unliganded thyroid hormone receptor alpha can target TATA-binding protein for transcriptional repression. Mol. Cell. Biol. 16: 281-287.

Forman, B.M., K. Umesono, J. Chen, and R.M. Evans. 1995. Unique response pathways are established by allosteric interactions among nuclear hormone receptors. Cell 81: 541550.

Glass, C.K., D.W. Rose, and M.G. Rosenfeld. 1997. Nuclear receptor coactivators. Curr. O pin. Cell. Biol. 9: 222-232.

Heinzel, T., R.M. Lavinsky, T.M. Mullen, M. Soderstrom, C.D. Laherty, J. Torchia, W.M. Yang, G. Brard, S.D. N go, J.R. Davie, E. Seto, R.N. Eisenman, D.W. Rose, C.K. Glass, and M.G. Rosenfeld. 1997. A complex containing N-CoR, mSin3 and histone deacetylase mediates transcriptional repression. Nature 387: 43-48.

Heyman, R.A., D.J. Mangelsdorf, J.A. Dyck, R.B. Stein, G. Eichele, R.M. Evans, and C. Thaller. 1992. 9-cis retinoic acid is a high affinity ligand for the retinoid $X$ receptor. Cell 68: 397-406.

Horiuchi, J., N. Silverman, G.A. M arcus, and L. Guarente. 1995. ADA3, a putative transcriptional adaptor, consists of two separable domains and interacts with ADA 2 and GCN 5 in a trimeric complex. Mol. Cell. Biol. 15: 1203-1209.

Horlein, A.J., A.M. N aar, T. Heinzel, J. Torchia, B. Gloss, R. Kurokawa, A. Ryan, Y. Kamei, M. Soderstrom, C.K. Glass, and M.G. Rosenfeld. 1995. Ligand-independent repression by the thyroid hormone receptor mediated by a nucl ear receptor corepressor. Nature 377: 397-404.

Horwitz, K.B., T.A. Jackson, D.L. Bain, J.K. Richer, G.S. Takimoto, and L. Tung. 1996. N uclear receptor coactivators and corepressors. Mol. Endocrinol. 10: 1167-1177.

Jacq, X., C. Brou, Y. Lutz, I. Davidson, P. Chambon, and L. Tora. 1994. Human TAFII30 is present in a distinct TFIID complex and is required for transcriptional activation by the estrogen receptor. Cell 79: 107-117.

Janknecht, R. and T. Hunter. 1996. A growing coactivator network. Nature 383: 22-23.

Kamei, Y., L. Xu, T. Heinzel, J. Torchia, R. Kurokawa, B. Gloss, S.C. Lin, R.A. Heyman, D.W. Rose, C.K. Glass, and M.G. Rosenfeld. 1996. A CBP integrator complex mediates transcriptional activation and AP-1 inhibition by nuclear receptors. Cell 85: 403-414.

Korzus, E., J. Torchia, D.W. Rose, L. Xu, R. Kurokawa, E.M. M clnerney, T.-M. Mullen, C.K. Glass, and M.G. Rosenfeld. 1998. Transcription factor-specific recruitments of coactivators and their acetyltransferase functions. Science 279: 703707.

Kurokawa, R., V.C. Yu, A. N aar, S. Kyakumoto, Z. Han, S. Silverman, M.G. Rosenfeld, and C.K. Glass. 1993. Differential orientations of the DNA-binding domain and carboxy-terminal dimerization interface regulate binding site selection by nuclear receptor heterodimers. Genes \& Dev. 7: 1423-1435.

Kurokawa, R., J. DiRenzo, M. Boehm, J. Sugarman, B. Gloss, M.G. Rosenfeld, R.A. Heyman, and C.K. Glass. 1994. ReguIation of retinoid signalling by receptor polarity and allosteric control of ligand binding. Nature 371: 528-531.

Leng, X., J. Blanco, S.Y. Tsai, K. Ozato, B.W. O'M alley, and M.J. Tsai. 1995. M ouse retinoid $X$ receptor contains a separable ligand-binding and transactivation domain in its $E$ region. Mol. Cell. Biol. 15: 255-263.
Lehmann, J.M., L. Jong, A. Fanjul, J.F. Cameron, X.P. Lu, P. Haefner, M.I. Dawson, and M. Pfahl. 1992. Retinoids selective for retinoid $X$ receptor response pathways. Science 258: 1944-1946.

Lemon, B.D., J.D. Fondell, and L.P. Freedman. 1997. Retinoid X receptor: Vitamin D3 receptor heterodimers promote stable preinitiation complex formation and direct 1,25-dihydroxyvitamin D3-dependent cell-free transcription. Mol. Cell. Biol. 17: 1923-1937.

Levin, A.A., L.J. Sturzembecker, S. Kazmer, T. Bozakowski, C. Huselton, G. Allemby, J. Speck, C. Kratzeisen, M. Rosemberger, A. Lovey, and J.F. Grippo. 1992. 9-Cis retinoic acid stereoisomer binds and activates the nuclear receptor RXR. Nature 355: 359-361.

Luo, Y., T. Gerster, and R.G. Roeder. 1992. A novel B cellderived coactivator potentiates the activation of immunoglobulin promoters by octamer-binding transcription factors. Cell 71: 231-241.

Lucibello, F.C., E.P. Slater, K.U. Jooss, M. Beato, and R. Muller. 1990. Mutual transrepression of Fos and the glucocorticoid receptor: Involvement of a functional domain in Fos which is absent in FosB. EMBO J. 9: 2827-2834.

M angelsdorf, D.J. and R.M. Evans. 1995. The RXR heterodimers and orphan receptors. Cell 83: 841-850.

M arks, M.S., P.L. Hallenbeck, T. N agata, J.H. Segars, E. A ppella, V.M. Nikodem, and K. Ozato. 1992. H-2RIIBP (RXR beta) heterodimerization provides a mechanism for combinatorial diversity in the regulation of retinoic acid and thyroid hormone responsive genes. EMBO J. 11: 1419-1435.

Minucci, S. and K. Ozato. 1996. Retinoid receptors in transcriptional regulation. Curr. Opin. Genet. Dev. 6: 567-574.

Minucci, S., M. Leid, R. Toyama, J.J. Saint, V.J. Peterson, V. Horn, J.E. Ishmael, N. Bhattacharyya, A. Dey, I.B. Dawid, and K. Ozato. 1997. Retinoid X receptor (RXR) within the RXR-retinoic acid receptor heterodimer binds its ligand and enhances retinoid-dependent gene expression. Mol. Cell. Biol. 17: 644-655.

Mizzen, C.A., X.J. Yang, T. Kokubo, J.E. Brownell, A.J. Bannister, H.T. Owen, J. Workman, L. Wang, S.L. Berger, T. Kouzarides, Y. Nakatani, and C.D. Allis. 1996. The TAF(II)250 subunit of TFIID has histone acetyltransferase activity. Cell 87: 1261-1270.

N agpal, S., M. Saunders, P. Kastner, B. Durand, H. N akshatri, and P. Chambon. 1992. Promoter context- and response element-dependent specificity of the transcriptional activation and modulating functions of retinoic acid receptors. Cell 70: 1007-1019.

Nagy, L., H.Y. Kao, D. Chakravarti, R.J. Lin, C.A. Hassig, D.E. Ayer, S.L. Schreiber, and R.M. Evans. 1997. N uclear receptor repression mediated by a complex containing SMRT, mSin3A, and histone deacetylase. Cell 89: 373-380.

Ogryzko, V.V., R.L. Schiltz, V. Russanova, B.H. Howard, and Y. N akatani. 1996. The transcriptional coactivators p300 and CBP are histone acetyltransferases. Cell 87: 953-959.

Oñate, S.A., S.Y. Tsai, M.J. Tsai, and B.W. O'M alley. 1995. Sequence and characterization of a coactivator for the steroid hormone receptor superfamily. Science 270: 1354-1357.

Perlmann, T., P.N. Rangarajan, K. Umesono, and R.M. Evans. 1993. Determinants for selective RAR and $T R$ recognition of direct repeat HREs. Genes \& Dev. 7: 1411-1422.

Sadovsky, Y., P. Webb, G. Lopez, J.D. Baxter, P.M. Fitzpatrick, G.E. Gizang, V. Cavailles, M.G. Parker, and P.J. Kushner. 1995. Transcriptional activators differ in their responses to overexpression of TATA-box-binding protein. Mol. Cell. Biol. 15: 1554-1563.

Sal bert, G., A. Fanjul, F.J. Piedrafita, X.P. Lu, S.J. Kim, P. Tran, 
and M. Pfahl. 1993. Retinoic acid receptors and retinoid $X$ receptor-al pha down-regulate the transforming growth factor-beta 1 promoter by antagonizing AP-1 activity. Mol. Endocrinol. 7: 1347-1356.

Schulman, I.G., D. Chakravarti, H. Juguilon, A. Romo, and R.M. Evans. 1995. Interactions between the retinoid $X$ receptor and a conserved region of the TATA-binding protein mediate hormone-dependent transactivation. Proc. Natl. Acad. Sci. 92: 8288-8292.

Schwerk, C., M. Klotzbucher, M. Sachs, V. Ulber, and H.L. Klein. 1995. Identification of a transactivation function in the progesterone receptor that interacts with the TAFIII10 subunit of the TFIID complex. J. Biol. Chem. 270: 2133121338.

Seol, W., M.J. Mahon, Y.K. Lee, and D.D. Moore. 1996. Two receptor interacting domains in the nucl ear hormone receptor corepressor RIP13/N-CoR. Mol. Endocrinol. 10: 16461655.

Shi, Y., E. Seto, L.S. Chang, and T. Shenk. 1991. Transcriptional repression by $Y Y 1$, a human GLI-Kruppel-related protein, and relief of repression by adenovirus E1A protein. Cell 67: 377-388.

Smith, C.L., S.A. Oñate, M.J. Tsai, and B.W. O'Malley. 1996. CREB binding protein acts synergistically with steroid receptor coactivator-1 to enhance steroid receptor-dependent transcription. Proc. Natl. Acad. Sci. 93: 8884-8888.

Tate, B.F., G. Allenby, R. Janocha, S. Kazmer, J. Speck, L.J. Sturzenbecker, P. Abarzua, A.A. Levin, and J.F. Grippo. 1994. Distinct binding determinants for 9-cis retinoic acid are located within AF-2 of retinoic acid receptor al pha. Mol. Cell. Biol. 14: 2323-2330.

Torchia, J., D.W. Rose, J. Inostroza, Y. Kamei, S. Westin, C.K. Glass, and M.G. Rosenfeld. 1997. The transcriptional coactivator $\mathrm{p} / \mathrm{CIP}$ binds CBP and mediates nuclear-receptor function. Nature 387: 677-684.

Tsai, M.J. and B.W. O'M alley. 1994. Molecular mechanisms of action of steroid/thyroid receptor superfamily members. Annu. Rev. Biochem. 63: 451-486.

Turner, B.M. and L.P. O'N eill. 1995. Histone acetylation in chromatin and chromosomes. Sem. Cell. Biol. 6: 229-236.

Wolffe, A.P. and D. Pruss. 1996. Targeting chromatin disruption: Transcription regulators that acetylate histones. Cell 84: 817-819.

Yang, X.J., V.V. Ogryzko, J. Nishikawa, B.H. Howard, and Y. Nakatani. 1996. A p300/CBP-associated factor that competes with the adenoviral oncoprotein E1A. Nature 382: 319-324.

Yang, Y.H., J.C. Chambard, Y.L. Sun, T. Smeal, T.J. Schmidt, J. Drouin, and M. Karin. 1990. Transcriptional interference between c-Jun and the glucocorticoid receptor: Mutual inhibition of DNA binding due to direct protein-protein interaction. Cell 62: 1205-1215.

Yao, T.P., G. Ku, N. Zhou, R. Scully, and D.M. Livingston. 1996. The nuclear hormone receptor coactivator SRC-1 is a specific target of p300. Proc. Natl. Acad. Sci. 93: 10626-10631.

Zaret, J.J. and K.S. Yamamoto. 1984. Reversible and persistent changes in chromatin structure accompany activation of a glucocorticoid dependent enhancer el ement. Cell 38: 29-38. 


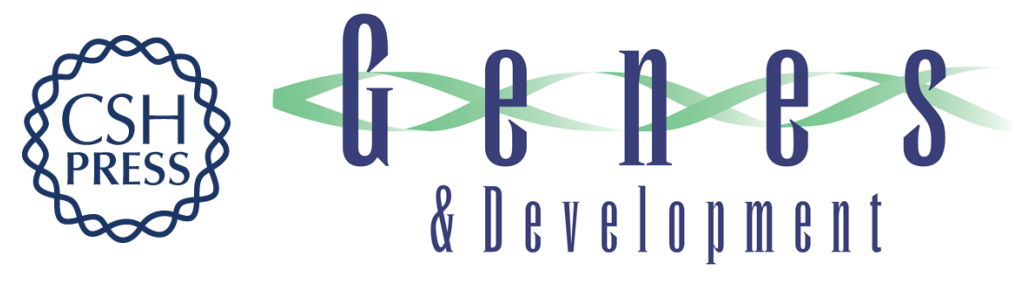

\section{The histone acetylase PCAF is a nuclear receptor coactivator}

Jorge C.G. Blanco, Saverio Minucci, Jianming Lu, et al.

Genes Dev. 1998, 12:

Access the most recent version at doi:10.1101/gad.12.11.1638

References This article cites 60 articles, 18 of which can be accessed free at: http://genesdev.cshlp.org/content/12/11/1638.full.html\#ref-list-1

License

Email Alerting Receive free email alerts when new articles cite this article - sign up in the box at the top Service right corner of the article or click here.

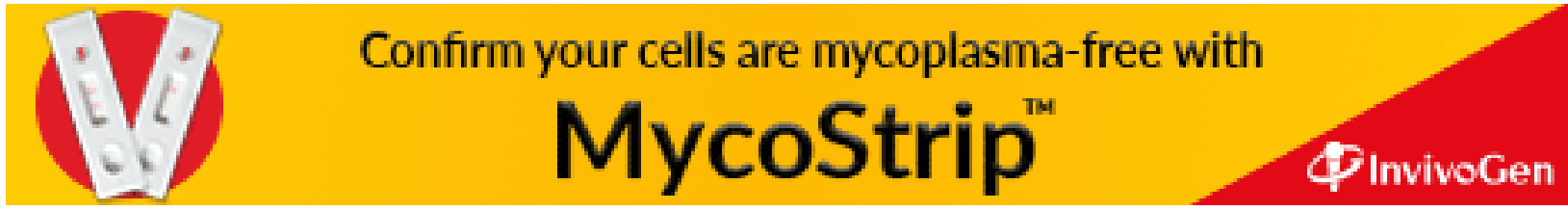

